Review Paper http://ajol.info/index.php/ijbcs http://indexmedicus.afro.who.int

\title{
Spread of bacterial wilt disease of potato in the highlands of Fouta Djalon, Republic of Guinea
}

\author{
Michel GBONAMOU ${ }^{1,3^{*}}$, Aya Carine N'GUESSAN ${ }^{2}$, Daouda $\mathrm{KONE}^{3}$ and \\ Mamady BAMBA ${ }^{1}$ \\ ${ }^{1}$ Institut de Recherche Agronomique de la République de Guinée BP 1523, Conakry. \\ ${ }^{2}$ Département de Biologie Végétale, UFR Sciences Biologiques, Université Péléforo Gon Coulibaly, BP 1328 \\ Korhogo, Côte d'Ivoire. \\ ${ }^{3}$ UFR Bio Sciences, Université Félix Houphouët Boigny d'Abidjan, Côte d'Ivoire. \\ *Corresponding author; E-mail: gbonamoum@gmail.com; Tel. (+224) 628679576
}

\begin{tabular}{lll}
\hline Received: 02-04-2020 & Accepted: 24-12-2020 & Published: $31-12-2020$ \\
\hline
\end{tabular}

\begin{abstract}
Bacterial wilt in potato (Solanum tuberosum) is caused by Ralstonia solanacearum in the highlands of Fouta Djalon in Guinea. The disease causes 50-70\% loss of potato in Guinea. The bacterium is transmitted either by imported tuber seeds or through seed exchanges between the farmers themselves from a contaminated area to bacteria-free areas or through irrigation waters along the fields. This is mainly a consequence of the informal potato seed system that prevails in Guinea. Because of the high price of seeds, farmers use several sources of supply. However, potato is an attractive cash crop in Guinea and the most important economic crop in Fouta Djalon. Most populations in the middle Guinea utilizes potato. The potato farmer's organization in Guinea, FPFD (Fédération des Producteurs du Fouta Djalon), is a model in West African sub-region because of its dynamism and organization with its 500 groups, 25 unions and more than 25,000 members. Training of potato growers in certified seed production techniques remains a major problem in Guinea that needed to be solved. This information is important for developing bacterial wilt disease management strategies through the training of farmers and state support for research.
\end{abstract}

(C) 2020 International Formulae Group. All rights reserved.

Keywords: Potato, disease, Ralstonia solanacearum, Guinea, spread.

\section{INTRODUCTION}

Potato (Solanum tuberosum) is one of the most important food crops for human nutrition in the world after wheat, rice and corn (FAO, 2017, Ngoh Dooh et al., 2020). Its economic importance is due to its short crop cycle, its adaptation to variable climatic and its rich nutritional composition (Ngoyi et al., 2020). The potato is an important crop in the human diet because it is able to provide significant calories per unit area. According to the FAO, its production has increased by $95 \%$ in 15 years in developing countries (Cromme et al., 2010). However, with climate change and increasing human population, the availability of potentially arable land is becoming a concern for expansion of potato production.

The potato was introduced in Africa through North Africa (Egypt) during the 1800s by British colonial officials (FAO, 2008). In West Africa, potato was first introduced in Nigeria in the 19th century by Christian 
missionaries and it was spread throughout the sub region (FAO, 2008). Potato was first introduced in Guinea between 1920-1922 by French Christian missionaries and the first field trials were conducted in 1974 in the district of Mali, using the variety Crazawa, introduced from Czechoslovakia (USAID, 2006).

Guinea has significant agricultural potential with 6,2 million arable hectares and precipitation between $1500-2800 \mathrm{~mm}$ per year. Guinea receives 6 months of rain and 6 months of dry season. Agriculture makes up 25\% of Gross Domestic Product and more than $80 \%$ of Guinea's population depends on agriculture (LPDA, 2015). Presently, potato cropping is practiced in the central highland of Fouta Djalon, between 1000 and $1700 \mathrm{~m}$ above sea level. The population density in this region is 70-106 people $/ \mathrm{km}^{2}$ (Bonnassieux et al., 2009). There are two main production areas; (i) Timbi-Madina in the district of Pita, where the FPFD has an area of 30,000 hectares very suitable for the cultivation of potatoes. FPFD has 70 hectares on a hillside and 35 hectares of lowland (Diallo et al., 2003). FPFD has seen its number of groups increase from 45 at its creation in 1993 to 500 in 2009 with 25 unions (Rosner et al., 2010). (ii) Soumbalako in Mamou district, where UGAS (Union des Groupements Agricoles de Soumbalako) has 276 hectares of land. In addition to these two areas, potato cultivation is gradually spreading to other districts (Dalaba, Mali, Labé Tougué) where agro-climatic conditions are favorable (USAID, 2006).

Since 1993, potato production has increased from 300 tons in 1993 to 15,000 tons in 2014 with 1,500 producer groups (FPFD, 2016). In Fouta, the agricultural calendar for potato has three periods; (i) the rainy season crop with planting in May-June and harvest in July-August; (ii) the September-October crop, the middle season crop with planting in September-October and harvest in NovemberDecember; (iii) the dry season crop with planting in December-January and harvest in February-March.

Despite this growth in production in Guinea, potato is subject to various diseases and pathogens resulting in significant losses of up to $50-70 \%$ of production in Guinea (Tolno et al., 2016). In 2016, potato cultivation was severely affected by potato late blight caused by Phytophthora. infestans since then it is unknown to potato growers in Fouta Djallon and losses have been estimated at about USD 44,315,860 (FPFD, 2016). Bacterial wilt caused by $R$. solanacearum was the major problem of potato in Guinea long before the arrival of the $P$. infestans. Some viral infections exist but they are not yet identified.

Bacterial wilt is spread through infected run-off water or comes from a contaminated plants and tillage tools or soil adhering to workers' shoes (Muthoni et al., 2014). The spread can come also from disbudding and stripping of plants. Bacterial wilt of potato caused by $R$. solanacearum is tuber borne and is primarily disseminated through infected seed tubers (Muthoni et al., 2014).

In Guinea, the potato fields are generally installed along rivers banks or on estates arranged by donors with the same water sources irrigating the plots. This contributes as a source of dispersal of $R$. solanacearum in these fields.

\section{GUINEA POTATO SEED SYSTEMS}

In Guinea, the potato seed supply system has evolved over time since the resumption of cultivation in 1993. There were 3 systems: i) the traditional system, ii) the agrobusiness Belgium system and iii) FAO system.

In the traditional system which is most common in West Africa, farmers buy certified seed in Europe from France, Holland and Belgium. In Guinea, every year, before the campaign, farmers meet to determine their annual needs. Administrators from all of the groups contact European suppliers and negotiate prices for the seeds and transport to the port of Conakry, Guinea and seeds are then transported to the union stores in Timbi Madina and Soumbalako. However, some private groups are importing seeds privately such as ETS Agro Business, in the district of Labe.

The agro-business system is no longer practiced these days but was used from 2003 to 2005 in Timbi Madian (Pita) and Labé districts; it was assisted by the Gand laboratory in 
Belgium. They multiplied certified seed in some fields in Guinea; these tubers were certified according to the protocol of that laboratory and reused as a seed for the next season (USAID, 2006). An in-vitro plantlets and micro-tubers production project was launched between the Kindia Research Center and the Gand Laboratory to continue production in Kindia. But the project did not continue due to lack of financial support from both producers' groups and the government.

The FAO system (TCP/GUI/3003) consisted of installing a generation of twelve certified seed producers in each area with financial support from FAO and technical support from the Agricultural Research Institute of Guinea (IRAG) and National Rural Promotion and Extension (SNPRV) agents. Each producer has one hectare, with all the material and input requirements for the production of certified seeds. At harvest, they should serve as a source of supply for other producers in the region (USAID, 2006).

In addition to these systems, a new cooperative project has been initiated between the International Potato Center (CIP) and Foulayah Biotechnology Laboratory for successful vitro-plants of potato varieties resistant to $P$. infestans and $R$. solanacearum in 2019. The multiplication of these varieties will be a source of certified resistant seed supply for producers.

This project will initially make it possible to provide certified seeds at a lower cost to producers compared to seeds imported from Europe. This will reduce the reuse of seeds from previous seasons and the exchange of contaminated or second generation seeds between the producers themselves. The dispersion of the bacteria from the contaminated areas to the free areas through these seeds will be greatly slowed down.

\section{BACTERIAL WILT OF POTATO}

Bacterial wilt, which is caused by the $R$. solanacearum species complex (RSSC), is one of the most devastating important and widespread bacterial diseases of vegetables in tropical environments (Buyela et al., 2017; Traoré et al., 2020). $R$. solanacearum is soil borne and affects a broad range of more than 450 species in 54 botanical families including monocots (Musaceae) and dicots (Solanaceae Potato, Pepper, Tomato, eggplant) in tropical, subtropical and warm temperature regions of the world (Phukan et al., 2019). The RSSC is composed of four evolutionary lineages, called phylotypes, whose origins have been inferred to Asia and Eastern Africa (phylotype I), America (phylotype II), Africa (phylotype III) and Indonesia (phylotype IV) (Fegan and Prior 2002; Wicker et al., 2012). The pathogen enters into the plant through the roots (Bihon et al., 2020); and colonizes the xylem vessels of its hosts. The typical above ground visible symptom is the rapid green wilt of the youngest leaves at the branches during the hottest part of the day, even where the soil is wet. When the disease develops under favorable conditions, the entire plant may wilt quickly and desiccate, although dried leaves remain green, and the plant eventually dies (Sedighian et al., 2020). In young stems, infected vascular bundles may become visible as long, narrow, dark brown streaks. For highly susceptible varieties, we can observe a collapse of the stem; when infection is well established, cross section of the stem can reveal brown discoloration of the infected tissues.

Below ground symptoms in the tubers consist in visible ring symptoms in the vascular bundle, easily seen when a tuber cross section is done. In potato, brown rot symptoms may be present in tubers at the later stage of disease. As infection progresses, the discoloration may extend into the cortex of the tuber. An oozing substance, which indicates the presence of bacteria cells, might also be observed in freshly cut section of infected tubers. Bacterial ooze is also visible at the eyes or the stolon of the tubers (Buyela et al., 2017). However, this bacterium can develop latent infection in symptomatic or asymptomatic hosts thus maintaining high populations for the future infection, e.g. Corton hirtus found in Guinea and common in most vegetable fields.

In Guinea, bacterial wilt has been observed in all the entire agro-ecological zones on most Solanaceae species, but the phylotype composition of the pathogen populations is still 
largely unknown. Few samples collected in Guinea have been analyzed by INRA France and phylotype III was reported on potato (Cellier et al., 2010). In Pita (Middle Guinea), most farmers have decided to change to cropping in raining season, because of the potato damage registered in 2018.

\section{MANAGEMENT OF BACTERIAL WILT IN GUINEA}

The common approach to control and eradicate bacterial wilt in potato is using the integrated combination of different measures such as phytosanitation, cultural practices, chemical control, biological, and host resistance (Karim et al., 2018). In Guinea, bacterial wilt management is based on the use of disease free certified seed tubers from Europe (France, Holland, Belgium) and uprooting the diseased plants. Plants around those attacked are immediately uprooted to contain the disease. The farmers throw the diseased plants out of the field into a deep pit and cover it with soil. They do this from planting to harvest (USAID, 2006). However, this technique is not effective because of the high price of the seed and lack of knowledge of the disease cycle by the farmers themselves (Tolno et al., 2016).

Seed for one hectare varies from 1,2 tons for small sized seed tubers to 1,5 tons for large tubers. Large tubers $(35-50 \mathrm{~cm})$ kilos costs 1, 54 USD so 2,314 USD per hectare. For small caliber $(28-35 \mathrm{~cm})$ a kilo costs 1, 70 USD corresponding to 2,043 USD by hectare. That price is not within the reach of all farmers. The price of seeds constitutes $51 \%$ of the input costs of the crop (USAID, 2006).

Because of these high prices, some farmers use tubers from the previous season saved for consumption as seeds after sorting and pre-germination. Others use seeds from informal sources, particularly via cross-border countries such as Senegal and Mali. In these cases, the seeds health cannot be guaranteed (Thomas-Sharmaa et al., 2016; Diop et al., 2020). In addition, quarantine is not possible in Guinea because the movement of the potato at the local level is uncontrolled and the potato system is largely informal (USAID, 2006;
Tolno et al., 2016). In addition, international borders are completely porous, which leads to the illegal import of potato seeds (ThomasSharmaa et al., 2016).

Besides quarantine, phytosanitary practices in the field such as disinfecting equipment and flood irrigation control can be the good prevention measures. However, in Guinea, $70 \%$ of production is done in the rainy season and water management is almost impossible. Farmers who cultivate in the intermediate season or the dry season use contiguous fields that have the same water source or use water sources with motorized water pumps that irrigate multiple fields. The use of resistant varieties on new soils should be a cultural method to prevent infestations (Kim et al., 2016); but, with the high population density and extensive livestock farming in the area, farmers cultivate in plots that cannot be changed each season (USAID, 2006). $R$. solanaceaum being a soilborne bacterium infests soils, watercourses, and survives for a long time.

To date, the development of a resistant, sustainable and universal potato variety for bacterial wilt has not yet been achieved and will be difficult (Muthoni et al., 2014). The large genetic variability within the $R$. solanacearum species complex makes the development of a resistant variety very difficult. The strong plant-pathogenenvironment interaction often makes the expression of plant resistance ineffective (Lebeau et al., 2011).

The control of the disease by chemicals remains very limited because the bacterium is able to survive in the soil and also live inside the xylem of the plant. The availability of systemic antibiotic for chemical control is still difficult (Hartman and Elphinstone 1994). A fumigant, chloropicrin, has shown positive effects in the control of the bacteria in other countries; however, it is not recommended in Guinea because of the adverse effects on the environment and also carcinogen potential of chemical (Li et al., 2017).

Crop rotations of 4-5 years excluding host plants has been recommended to control the bacteria in the soil (EPPO, 2011; Ayana et 
al., 2017). However, in Guinea there is not enough land for crop rotation practices. Alternative rotations such as beans and maize may not interest small farmers due to low economic returns relative to potatoes and cropping period involved, and, therefore, rotation for disease control may not be viable (Kaguongo et al., 2010).

Another technique currently being tested in different combinations is the use of suppressive crops (Raphanus sativus, Allium fistulosum, etc.). These plants release volatile chemicals (allelochemicals) to suppress soilborne plant pathogenic bacteria, (Fernandes et al., 2012; Yulia et al., 2015). With the multitude of plants with repellent or suppressive effects, this test should be reproduced in Guinea.

Despite the existence of measures to control bacterial wilt, small Guinean farmers do not use any of these control strategies such as the use of resistant varieties, the use of sanitizing plants, crop rotation, etc. This is explained by the lack of knowledge about the disease by these small farmers (USAID, 2006). They usually have a limited knowledge about the causal agent of this disease and about disease management practices.

\section{SOME ACTIVITIES IN PROGRESS ON BACTERIAL WILT IN GUINEA}

Given the economic impact of bacterial wilt on potato production in the highlands of Fouta Djalon, a study on the "Genetic diversity" of $R$. solanacearum, the causative agent of the disease, has been initiated by Institute of Agronomic Research of Guinea (IRAG). Surveying and sampling with symptoms are carried out in the main potato production areas of Fouta Djalon in August 2018 and March 2019 (Figure 1). This activity is important for developing wilt management strategies including breeding for resistance (Gbonamou et al., 2020).
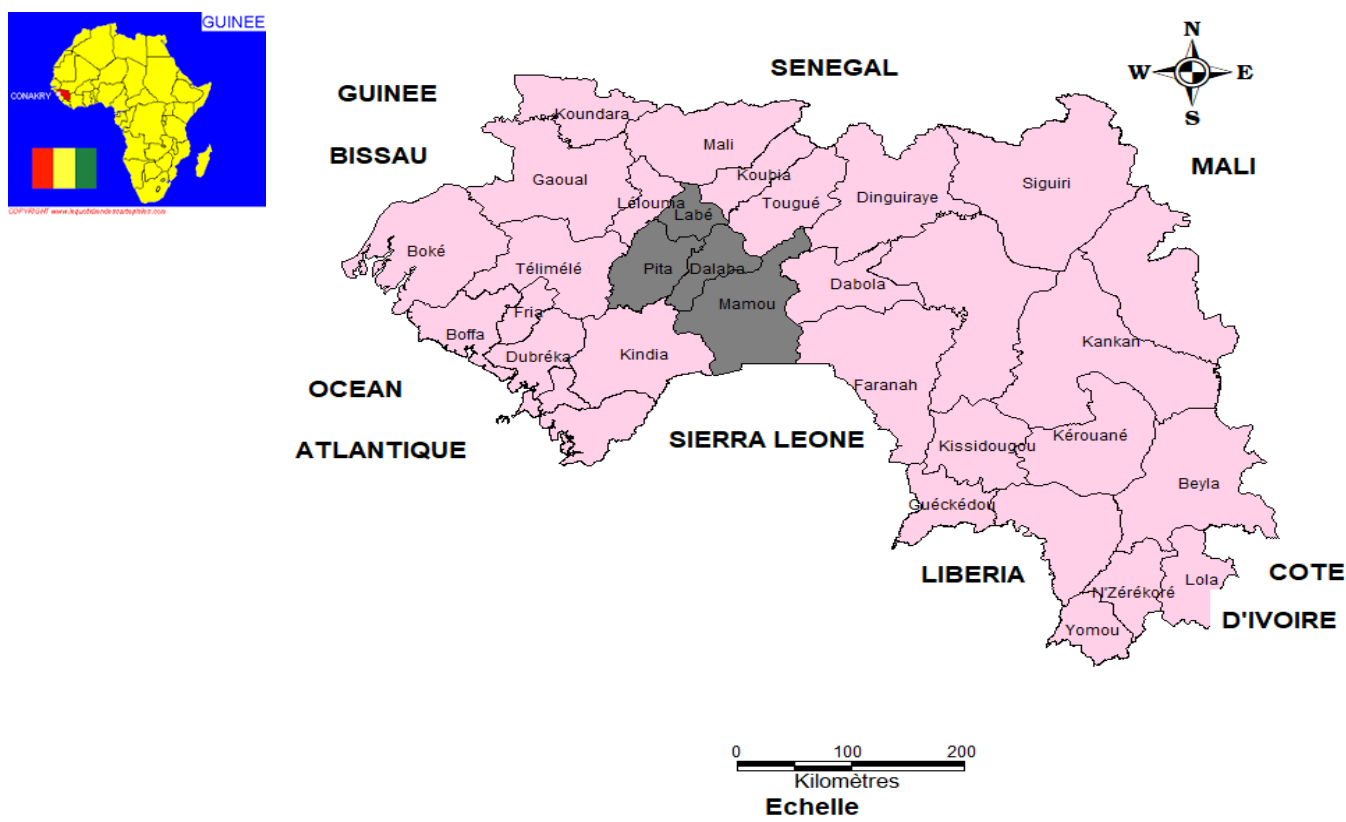

\section{LEGENDE}

Sites

Projection: Long/Lat WGS84

Figure 1: Map of the prospection zone in Middle Guinea. 


\section{Conclusion}

Potato, one of the top cash crops in Guinea is mainly grown in the highlands of Fouta Djallon (1500-2000 m altitude). There are two major potato producers' organizations in Guinea: FPFD and UGAS (Union des Groupements Agricoles de Soumbalako) who exclusively manage the sector. Bacterial wilt disease is one of the major problems in potato production in Guinea causing enormous losses. The disease is spread through seed exchange between farmers from contaminated areas to another by unrecognized transmission methods. The lack of knowledge of the causal pathogen responsible for the disease and of management techniques in the production areas is the main cause of the spread, thus hampering the development of the sector. The activity on the study of the genetic diversity of the $R$. solanacearum is a beginning of hope for the resolution of the problem since it will allow Institute of Agronomic Research of Guinea (IRAG) to find Resistant/Tolerant potato varieties to improve production and productivity. However, given the importance of the sector, the government must supervise, train and support the sector through the establishment of a certified seed import network which constitutes $51 \%$ of the crop exploitation account. That is possible through the support of APROCA (National Agency for Rural Promotion and Agricultural Council) and IRAG (Institute of Agronomic Research of Guinea). Producer training on disease and insect management technics both in production and conservation are needed. Capitalization of research results from others countries and support of the Biotechnology Laboratory at the Foulayah Research Center in Kindia for the production of pre-basic micro-tubers and collaboration with others international institutions such as the CIP and IITA are critically required.

\section{COMPETING INTERESTS}

The authors of this work declare on their honor that they have no competing interest.

\section{AUTHORS' CONTRIBUTIONS}

GM carried out the field visit, discussed with the farmers and collected the withered plants with NAC and wrote the manuscript; $\mathrm{BM}$ contributed to the isolation work at the Foulayah agronomic research laboratory in Kindia in Guinea. KD participated in the technical and scientific assistance of the work. All authors have received and approved the final version of this work.

\section{ACKOWLEDGMENTS}

Our thanks to the WAAPP project (West Africa Agriculture Productivity Program) through FORESGUI (Fondation pour le Progrès de la Recherche Scientifique en Guinée) for their financial support in carrying out this work.

\section{REFERENCES}

Ayana G, Fininsa C. 2017. Effet of crop rotation on tomato bacterial wilt (Ralstonia solanacarum) and survival of the pathogen in the rhizospheres and roots of the different crops in Ehtiopia. Int. J. Phytopathol., $\quad$ 5(03): $\quad 81-88$. DOI: https://doi.org/10.33687/phytopath. 005.03.1932.

Bihon W, Chen JR, Kenyon L. 2020. Identification and characterization of Ralstonia spp. causing bacterial wilt disease of vegetables in Mali. J. Plant Pathol., 102: 1029-1039. DOI: https://doi.org/10.1007/s42161-02000631-1.

Bonnassieux A, Diallo KL. 2009. L'expansion récente du maraîchage de rente au FoutaDjalon: dynamiques spatiales et organisationnelles et recompositions sociales. Les Cahiers d'Outre-Mer, 247: 345-371.

DOI : https://doi.org/10.4000/com.5685

Buyela DK, David MM, David MM, George TO, Pascaline J. 2017. Isolation and characterization of Ralstonia solanacerum strains of tomato wilt disease from Maseno, Kenya. Journal of Asian Scientific Research, 7(9): 404-420. DOI:

10.18488/journal.2.2017.79.404.420.

Cellier G, Prior P. 2010. Deciphering phenotypic diversity of Ralstonia solanacearum strains pathogenic to potato. Phytopathology, 100(10): 1250- 
1261. DOI: 10.1094/PHYTO-02-100059.

Cromme N, Prakash AB, Lutaladio NB, Ezata F. 2010. Potato value chains Technical and policy options for developing countries. FAO, Rome, Italy, p.150.

Diallo AB. 2003. Etude de Capitalisation de la filière pomme de terre en Guinée. Rapport d'activité du Projet d'appui à la dynamisation des filières vivrières (DINAFIV), 18 p.

Diop P, Sylla ES, Diatte M, Labou B, Diarra K. 2019. Effect of cut seed tubers and pregermination on potato tuber yield. Int. $J$. Biol. Chem. Sci., 13(7): 3157-3163. DOI: https://dx.doi.org/10.4314/ijbcs.v13i7.15

EPPO/EOPP (Eurpean and Mediterrannean Plant Protection Organisation). 2020. Global database (datasheetreport/45009\#REF-DDB183911) EPPO Global database. EPPO/EOPP, Paris, France. https://www.cabi.org/isc/datasheet/4500 9\#REF-DDB-183911.

FAO. 2017. La situation Mondiale de l'alimentation et de l'Agriculture. Mettre les systèmes alimentaires au service d'une transformation rurale inclusive. Food and Agriculture Organization, Rome, Italy, $201 \mathrm{p}$.

FAO. 2008. International year of potato, Food and Agriculture Organization of the United Nations. Rome, Italy.

Fegan M, Prior P. 2005. How complex is the "Ralstonia solanacearum species complex", In Bacterial wilt disease and the Ralstonia solanacearum species complex, Allen C, Prior P, Hayward AC (Eds.). St. Paul- APS press : USA; 449461.

Gbonamou M, N'guessan AC, Chen JR, Kone D, Bihon W, Lawrence K. 2020. First phylotype analysis of Ralstonia solanacearum causing Eggplant bacterial wilt in the Republic of Guinea. Journal of Animal \& Plant Sciences, 46(2): 81878196.

DOI: https://doi.org/10.35759/JAnmPlSci.v462.3.

Hartman GL, Elphinstone JG. 1994. Advances in the control of Pseudomonas solanacearum race 1 in major food crops. In Bacterial wilt: The disease and its causal agent, Pseudomonas solanacearum, Hayward AC, Hartman GL (eds.). CAB International: Wallingford-UK; 157-177.

Kaguongo WP, Ng'ang'a NM, Muthoka N, Muthami F, Maingi G. 2010. Seed potato subsector master plan for Kenya (20092014). National Potato council of Kenya, Ministry of agriculture, Kenya, 124 p.

Karim Z, Hossain MS. 2018. Management of bacterial wilt (Ralstonia solanacearum) of potato: focus on natural bioactive compounds. J. Biodivers. Conserv. Bioresour. Manag., 4(1): 73-92. DOI: https://www.cabi.org/10.3329/jbcbm.v4i 1.37879

Kim SG, Hu OS, Ro NY, Ko H, Rhee JH, Sung JS, Ryu K, Lee S, Baek HJ. 2016. Evaluation of resistance to Ralstonia solanacearum in Tomato genetic resources at seedling stage. Plant Pathol. J., 32(1): 58-64. DOI: https:// doi.org.10.5423/PPJ.NT.06.2015.0121.

Lebeau A, Daunay MC, Frary A, Palloix A, Wang JF, Dintinger J, Chiroleu F, Wicker E, Prior P. 2011. Bacterial wilt resistance in tomato, pepper, and eggplant: genetic resources respond to diverse strains in the Ralstonia solanacearum species complex. Phytopathology, 101:154-165. DOI: https:// doi.org.10.1094/PHYTO02-10-0048.

LPDA (Lettre de Politique de Développement Agricole, Vision 2015). 2007. Ministère de l'Agriculture, de l'Elevage, de l'Environnement et des Eaux et Forêts, Guinée, 82 p.

Li J, Huang B, Wang Q, Li Y, Fang W, Yan D, Guo M, Cao A. 2017. Effect of fumigation with chloropicrin on soil bacterial communities and genes encoding key enzymes involved in nitrogen cycling. Environ. Pollut., 227: 534-542.

DOI: 10.1016/j.envpol.2017.03.076.

Muthoni J, Kabira J, Shimeli H, Melis R. 2014. Spread of bacterial wilt disease of potatoes in Kenya: Who is to blame? International Journal of Horticulture, 
4(3): $\quad 10-15$ DOI: 10.5376/ijh.2014.04.0003.

Phukan T, Kabyashree K, Singh R, Sharma PL, Singh N, Barman A, Jena BR, Ray SK, 2019. Ralstonia solanacearum virulence in eggplant seedlings by the leaf-clip inoculation. Phytopathology research, $\mathbf{1}$ : 23. DOI: https://doi.org/10.1186/s42483019-0030-x.

Ngoh Dooh JP, Boydoul FU, Mandjerembe A, Thoupou Tsouala DB, Hawaou Adagoro DB, Kosma P, Ambang Z. 2020. Inventory of the potato diseases and impact on growth and yield traits in far North Cameroon. Int. J. Biol. Chem. Sci., 14(8): 2826-2836. DOI: https://dx.doi.org/10.4314/ijbcs.v14i8.14 Ngoyi AN, Masanga GK, Bila HM, Yashima AY, Milomba MM Ndjibu LN, Baboy LL. 2020. Effet des amendements organiques sur la croissance et le rendement de la pomme de terre (Solanum tuberosum) cultivée sur un sol dégradé dans la région de Kabinda, République Démocratique du Congo. Int. J. Biol. Chem. Sci., 14(5): 1812-1819. DOI: https://doi.org/10.4314/ijbcs.v14i5.24

Rosner PM, Rother L. 2010. Bilan de l'assistance technique à la fédération des paysans du Fouta Djallon (FPFD) en Guinée: 15 ans d'accompagnement, Evaluation et capitalisation Ex-post, AFD, N³2, ISSN 1958-590X, p.79.

Sedighian N, Mendes O, Poleij L, Bonants P, Van der Wolf J, 2020. Detection of Ralstonia pseudosolanacearum in drain water based on concentration, enrichment and the use of a duplex TaqMan PCR test. Bulletin OEPP/EPPO Bulletin, 50(2): 111.

Strange RN. 2003. Introduction to potato pathology. John Wiley \& Sons Ldt.: UK. Thomas-Sharmaa S, Abdurahman A, Alic S, Andrade-Piedrad JL, Bao S,
Charkowskif AO, Crook D, Kadian M, Kromann P, Struik PC, Torrance L, Garretta KA, Forbes GA. 2016. Seed degeneration in potato, the need for an integrated seed health strategy to mitigate the problem in developing countries. Plant Pathology, 65(1). DOI: https://doi.org/10.1111/ppa.12439.

Tolno E, Kobayashi H, Ichizen H, Esham MM, Balde BS. 2016. Potato production and supply by smallholder farmers in Guinea: An economic analysis. Asian Journal of Agricultural Extension, Economics \& Sociology, 8(3): 1-16. DOI: https://doi.org/10.9734/AJAEES/2016/2 1726.

Traoré O, Wonni I, Boro F, Somtore E, Zombré CT, Dianda OZ, Wicker E, Ilboudo P, Ouedraogo LS, Somda I. 2020. Evaluation of the 19 varieties and accessions of tomato against bacterial wilt in Bobo-Dioulasso, Burkina Faso. Int. J. Biol. Chem. Sci., 14(8): 2870-2879. DOI: https://dx.doi.org/10.4314/ijbcs.v14i8.17

USAID (Agence des Etats-Unis d'Amérique pour le Développement International). 2006. Production et commerce de la pomme de terre en Guinée, étude de préfaisabilité. USAID, Guinée, p.46.

Wicker E, Lefeuve P, De Cambiaire JC, Lemaire C, Poussier S, Prior P. 2012. Contrasting recombination patterns and demographic histories of the plant pathogen Ralstonia solnacearum inferred from MLSA. The ISME Journal, 6(5): 961-974.

DOI: https://doi.org/10.1038/ismej. 2011. 160.

Yulia A, Yanetri AN, Toyota K. 2015. Recent trends in control methods for bacterial wilt diseases caused by Ralstonia solanacearum. J. Microbes Environ., 30(1): 1-11. DOI: 10.1264/jsme2.ME14144. 